\title{
The Role of Land Ownership on Tourist Offer: A Case Study in Himara
}

\author{
Lindita Mukli \\ "Aleksandër Moisiu" University of Durrës, \\ linditamukli@gmail.com \\ Rezarta Mersini \\ "Aleksandër Moisiu" University of Durrës, \\ rmersini@hotmail.com
}

\section{Doi:10.5901/ajis.2013.v2n8p691}

\section{Abstract}

The paper focuses on the land ownership, for understanding its impact on tourist offer. The thrust to this work relates to the transformation of the Albanian society after 1990 and implementation of the Law no. 7501 "On Land". In a short period the land scattered. The pressure on agricultural land increased significantly, especially near major cities, main roads and coastal area. Land use in these areas is not exclusively agricultural, always making use on current competition between different economic sectors. The Land Law created a new group of owners. Earth got fragmented among some members, a phenomenon that affected the tourist offer. Pressure on land in the coastal area grew. The aim of this paper is to identify the relationship and interdependences between tourism supply and land ownership. This analysis was conducted in the municipality of Himara, an area of significant tourism development, which increases the possibility of agricultural as well as urban usage of the land. From the analysis of the surveys conducted in a sample area of study we conclude that heritage and the process of land distribution deepens the traditional problems of extreme agricultural land fragmentation and this fragmentation is more problematic in the coastal zone. Development growth of tourism in the area is increasing the level of land fragmentation.

Keywords: Land ownership, farmer, agriculture, tourism, tourism offerings, Himara city.

\section{Introduction}

Land relations organizing is one of the main explanations of organizing society throughout human history. Hence the explanation of the first stages of economic organization of humanity is tied to land ownership.

Tourism sector in Albania recognizes a later development and has played for a long time a marginal role in the economy. Although early on the tourism sector was related to the Italian occupation, the tourist sector took a boost in development during the communist period.

Relatively quickly isolation of the country turned tourism sector, towarad workers and local leaders. Economic and social opening of Albania after 1991, gave a new momentum to the country's tourism development particularly that of coastal areas, using individual private investment, which caused a structured small-scale tourism, coupled with extreme cleavage of local landscape.

\section{Theoretical overview}

Theoretical framework in which we support in this study, is that the distribution of land is based of its value if it is agronomic, urban, etc. Our theoretical analysis will be based on the concepts of land value and the distribution of it between family members.

To study the strategies of farmers on the land, we must keep in mind the triple character of the land:

1. land as a production tool;

2. land as reserve assets;

3. earth family fortune.

As Rodriguez (2000) emphasizes, land prices and rent value are determined according to the report and conflicts that exist between these three functions. Activities that use the territory are not the same. Traditional activities are modified and new activities are installed in space at the same time that rural families integrate into the global society, 
thereby reducing the weight of agriculture in their income. Already, land usage reflects the social position of the family, its way of life and the creation of income (agricultural production, other activities outside agriculture), as well as the main features of land (location, fertility, etc..) (Guri, 2002).

Earth takes various functions ranging from goals and family situation which is the land owner and determines the level of priority that gives each function. It should be taken into consideration the new features of land that make the situation more complex. Thus land owns age means more and more benefits that arise from environmental amenities which are connected directly to the land. So there is no land values which are exclusively agricultural, rather, nonagricultural value becomes more important than agriculture. Baptista (1994) states that "the issue of land is not separated from agricultural definitive", but on the other hand, increasingly, land interests are not related to agricultural area.

To analyze the process of inheritance, in this study we present an overview of the structure of land ownership in the last century, to analyze their existing characteristic elements and their role in the decision making process of farmers in terms of competition between agriculture and other land uses.

\subsection{Agrarian reforms}

Agrarian reforms were elements which left significant marks on agricultural land administration in the future (Tomasevich, 1958).

Even in Albania, under the slogan "land belongs to the tiller", August 25, 1945, approved the agrarian reform law. The objective was owning more than 145000 families with land who had no land available, or surfaces that have not passed the 5 ha.

Table 1. The level of expropriation in Albania by agrarian reform in 1946

\begin{tabular}{|l|c|c|c|}
\hline Expropriation & Number of farmers & Surface in Ha & Olive roots \\
\hline Totaly & 8714 & 54499 & 287744 \\
\hline Partly & 10641 & 64997 & 125259 \\
\hline Former state property & & 50000 & \\
\hline Former religious properties & & 3163 & 61024 \\
\hline Total & 19355 & 172569 & $\mathbf{4 7 4 2 2 7}$ \\
\hline
\end{tabular}

Source: Civici, 2001

Beneficiaries were given land ownership "Sealant", which legally recognized ownership of the new owners of the land. On the other hand, the new owners had no right to trade these lands which blocked the land market (Aliko, 2001).

\subsection{Collectivization}

Along with land distribution collectivization began. Building collective cooperatives, was associated with elements as well as economic policy. Schmitt (1993) identifies as most important: i) increase the level of control over agricultural farms, ii) enable the integration collectivization of its agriculture more efficiently in the planned economy.

The process of collectivization in Albania recognizes two main phases:

1. From 1946 to 1955. At this stage the villagers membership in cooperatives was not mandatory (Civici, 1997). Albanian agriculture was generally private and only $5.4 \%$ of the total agricultural area was organized in the form of cooperative production.

2. 1956-1970. During this period collectivization in the cooperative binding of type "kolkoz" more than 300000 hectares or about $74 \%$ of the total Albanian agricultural. In this period, the level of surface owned by rural families did not exceed 21000 ha or 3.5\%.

In 1976, de juro land collectivization ended in Albania with the announcement of the new Constitution which stipulates land as state property.

\subsection{Decollectivization process}

Approval of Law no. 7501 "On Land" approved on 31. 07. 1991, the parliament decided that collectivist organizations liquidation and distribution of land to all members of cooperatives in the area and equal quality. Beneficiaries of this law 
would be rural households as former members of agricultural cooperatives by 31 July 1990 .

\section{Methodology}

The study is based on a structured survey which was developed in Himara with intellectuals, teachers, farmers in the area who have benefited from the implementation of Law no. 7501. The questionnaires were structured in such a way that it contains the information needed to answer a hypothesis: "Individual strategies of coastal farmers in the distribution of land among heirs, support the social unit rather than the productive one leading to reducing the stability even more in this farm areas".

For processing questionnaires, SPSS software (descriptive Statistics, Frequencies, Compare Means, Independent Samples T-test) and Mega Stat (Hypothesis Test, Compare Two independents Groups) were used.

Himara area selection is made for the simple reason that it has land area of socio-economic categories as diverse as e.g.: agricultural land, Orchards (olives), has developing tourism, urbanization.

Research questions:

1. What are the characteristics of the decision making about the allocation of land in the family?

2. What are the effects of inheritance strategies in agricultural farms of the area and the future of these entities?

\section{Results}

\subsection{Descriptive Statistics}

Analysis of the results of the surveys will attempt to explain and support the hypothesis of the study.

The following table provides information about the 7501 law enforcement in the area.

Table 2. Land distribution in 1991

\begin{tabular}{|l|l|l|}
\hline Village/City & Land division form & Members who do not live in the area \\
\hline Himara & $\begin{array}{l}\text { Return to properties before collectivization / } \\
\text { The newcomers do not benefit }\end{array}$ & Benefit as gift \\
\hline Vuno & Return to properties before collectivization & Benefit as gift \\
\hline
\end{tabular}

\section{Source: Authors}

Leaving out the ownership of newcomers in Himara, even when the latter were members of the cooperative who were decollectified, shows two essential elements: i) the implementation of this law in the area has overlooked its essence, which stood in an equal owning between villagers and former villagers ii) the core community is very strong that has enabled this kind of application and still more that made it acceptable even by non beneficiaries.

From the above data we think that in Himara no law is implemented nor law. 7501 nor any of its properties. This has led to distortions and abuses which brought major conflicts and preventing further development especially in the area of tourism development. This is due to the uncertainty in the management of properties acquired by Law 7501. This uncertainty is related to the land in two main elements: i) no compensation of former owners, who remain potential elements for Conflict and insecurity between farmers, ii) strong political debates on the implementation of the reform.

From the questionnaires it is clear that there is a tradition in the inheritance of land in the area. Reference historical heritage helps farmers in the allocation of land among offspring. In Himara land division is performed only on indigenous peoples and not for incoming residents.

Another factor that affects the tradition of land inheritance is the history. The settlers claimed that they would share the land equally among all children, without excluding women, as all are benefiting from reforms. Natives were cut in their decision making, only boys.

Another element is the land value. In our land, the area receives a significant amount of surface and especially those which are located near the coast. 
Figure 1. Land distribution in the area

Source: Authors

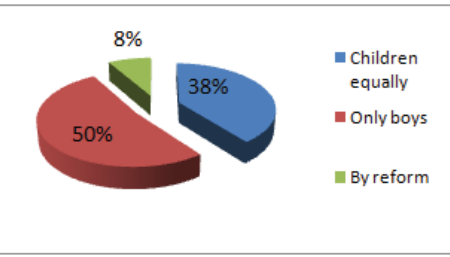

In most surveys we note that there is a tradition which is stabilizing in the area. The decision on the allocation of land among family members are taken by the head of the family.

\subsection{Equality in quality or quantity}

Decollectivization process in 1991, formed in Albania many small farms in the zone. The issue of land inheritance, is not only related to the right to have land or not, but even with the surface of the latter. The study shows that the area of land allocation is performed by two main vectors: soil quality and value of the latter. Children who have the right to inherit land, take equal area of agro-plots with the same quality. This is not surprising, we can say that farmers can keep their strategies, elements of the reform of 1991. However, considering that the principles of the Law no. 7501, are not only used in farming families, they are coordinated with other principles that have to do with the value of the land. So unlike equity required under the Law no. 7501, is worth more than physical. Now the division of land among children preserves equality in value and not on the surface. The principle of economic logic indicates that value already exists in the area, highlighting land as development support, rather than as a means of agricultural production land. If we make a comparison between the model implemented in 1991 and the one implemented in 2010, it is observed that they are not much different. Moreover the model implemented in 2010, is modified but has integrated a strong value component, which was not true to the model implemented in 1991.

To analyze the variability of distribution of land in the coastal area and in other areas using t-test.

Hypotheses, $\left\{\begin{array}{l}H_{0}: \mu_{1} \geq \mu_{2} \\ H_{1}: \mu_{1}<\mu_{2}\end{array}\right.$ where $\mu_{1}$ the average size of farms on the coast and the $\mu_{2}$ average size of farms in other areas.

Figure 2. Mega Stat results of questionnaires for data
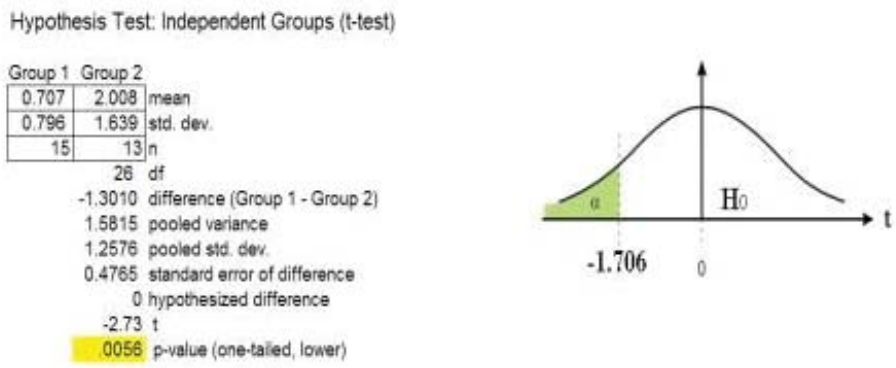

Source: Authors

For a $95 \%$ level of security, we reach the conclusion that the average area of farms in the coastal area is less than the average area of farms in other areas, because from SPSS we have $p$-value $(0,0056)$ which is smaller than the level of significance, indicating that the Ho hypothesis is not true. It is clearly seen from the survey results that the average farm area is 1.3 ha ( 0.7 ha in the coastal zone and in the next 2 ha).

This fragmentation has its source in '91, where the parcels were tourist interest, are shared among many farmers 
and each of them has an area of everal hundred m2. This fragmentation reduces interest and it's difficult for investors to invest in the development of tourism in the area, the fact that to have a large area you will need to perform more transactions with owners. In these conditions, the market vendors operate buyers who are interested in having reduced surface even more fragmented landscape.

\section{Conclusion}

The study noted that the strategy of farmers in land allocation considers the family unit and not the product. In these conditions, further fragmentation of these areas will be the last issue totally out possibility of being competitive.

The transition from considering land as a natural resource production in non-renewable, through its evaluation, implicitly means that the family unit has broken the traditional links. We must be aware that considerable pressure through the market, families have taken a position that accepts this change. This makes us think that in the future, these lands will be increasingly on the market until the latter have a request for them.

Land area is seen by the owners of the property as a security rather than as a production tool. If it were considered as a production tool, then sharing strategies would be manufacturing unit that will prevail, no physical separation between the seed of the land, preserving the unity of the land to maintain the ability to be competitive in farms local markets and beyond.

The extreme fragmentation of land is due to the fact that land is benefited by all family members and not inherited from the father, who has no moral legitimacy to exclude some family members benefit from the process of land.

Land division from in our area of study, has been definitely damaged the land and its effectiveness in the area. That little land that was divided by the 1991 law, or that belonged to owners during decollectivization, divided several times just a few years after the first division. Eventually between production unit (farm), and social unit (family) in our area of study preferred the latter as the most important and most essential for the future. In these conditions, we say that the family and the farm is not what prevails in the land distribution process.

Strengthen the development of tourism in the area will increase the level of fragmentation and final release of land from agriculture.

\section{Recommendations}

The study enabled us to recognize the problems of the land market and the tourism offer in Himara, the solution of which can contribute with some recommendations.

1. The study found there was even a problem with the reluctance of farmers to finance their land, because there is a tension and uncertainty to property due to property disputes. To solve this problem it is the duty of the government to improve legislation, where no precise definition of land ownership and the amount of compensation to former owners, because lingering property disputes and compensation to former owners and makes domestic investment foreign limited, or not been stopped because of safety for the investment.

2. It is the duty of the municipal offices to determine which areas are to be protected and which are intended to be built. That the zoning to be efficient and to be respected for a long term and furthermore apply, because the history of the Albanian transition has shown that this method is observed or very difficult, or more often not respected at all.

3. Although the law no. 9244 , dated 17.06 .2004 to regulate the relationship between the right of private ownership of land and its obligation to protect a national treasure, is not able to build adequate policies and determine land use. To prevent damage, the limited physical alternation of land and improve its management should develop national policies for the taxation of land transactions.

4. The proposed transaction tax is a tax that applies at the time of the transaction. This is because the registration of the transaction remains a key element in that state institutions have full restrictive capacity regarding the applicability of the tax and its payment by buyers.

5. Tax rate set in a transaction subject should change depending on the traded area. So apply a higher tax fee if marketed a small area and reduce the tax on larger area. The objective is to increase the tax on transactions over land areas in the coastal zone. This fee helps maintain the fragmentation of parcels. Since this method should be functional public institutions to be able to implement this policy, because currently these institutions have indicated that they are unable to provide a satisfactory service even if the buyer is willing to pay.

6. The development of tourism in the area leaves much to be desired, it has significant shortages in basic 
infrastructure elements, thus by invalidating the natural charm of the area. State institutions should adapt an integrated development strategy based on tourism and environmental advantages and focused on the environmental carrying capacity of the area.

\section{References}

Aliko, H. (2001). "The impact on the development of a land market in Albania caused by the restitution and compensation of a agricultural land in Transition, Institutions, and the Rural Sector". Center for the Study of transition and Development.

Baptista, F. (1994). "A agricultura e a questao da terra-do esto novo à comunidade europeia". Analise Social XXXIX, 128, 907-921.

Civici, A. (1997). "Evolution des politiques economiques et agricoles de 1945-1995". Options Méditerranéennes, Sér.B, (15), 15-50.

Civici, A. (2001). "Evolution des politiques foncières et dynamique des espaces ruraux en Albanie". In Terres méditerranéennes. Le morcellement, richesse ou danger, 127-146, Karthala-Ciheam.

Guri, F. (2002). "Transformation des exploitations agricoles et reorganization foncière sur la côte albanaise". Master's thesis, Ciheamlam, Montpellier, 3191 Rte de Mende, 34095 Cedex 5 Montpellier, France.

Rodriguez, O. (2000). "Utilisaçao do territorio e propriedade fundi aria". Instituto Superior de Agronomia.

Schmitt, G. H. (1993). "Agrarian reform in eastern europe after World War II". American Journal of Agricltural Economics, 75 (3), 845 850.

Tomasevich, J. (1958). "Agriculture in Eastern Europe". Annals of the American Academy of the Political and Social Science, 317, 44-52. 